\title{
COMPLEX OF METHODS OF IMAGINATIVE PSYCHOTHERAPY OF THE BODY IN HEALTHY PSYCHOTECHNOLOGY “RIC": EFFICIENCY AND FEATURES OF APPLICATION
}

\author{
Tamara B. Khomulenko \\ Doctor of Psychological Sciences, Professor, Head of the Department of Practical Psychology \\ G.S. Skovoroda Kharkiv National Pedagogical University \\ E-mail:tamaraKhom108@gmail.com,https://orcid.org/0000-0003-3962-0795 \\ Kramchenkova V.O. \\ G.S. Skovoroda Kharkiv National Pedagogical University \\ Karina I. Fomenko \\ Ph.D. in Psychological Sciences \\ G.S. Skovoroda Kharkiv National Pedagogical University \\ E-mail: karinafomenko1985@gmail.com, https://orcid.org/0000-0003-2511-6803
}

Ya.L. Obukhov-Kozarovitsky

\begin{abstract}
Decrease in the level of health is considered today as a social, general cultural problem. In modern Ukraine, there is an acute problem of using psychological technologies for healing, fostering a conscious attitude to one's health, which is caused by a contradiction between the fairly high objective requirements of society for health, harmonious development of people and a rather low level of respect for one's body and wellness culture, as well as a general deterioration health of citizens. The article is devoted to the development of health-improving psychotechnology and assessment of its effectiveness based on the study of the dynamics of verbalization of bodily and subjective assessment of health as a result of its application. A generalization of the results of a theoretical analysis of the health problem and the psychological mechanisms of its provision is presented. The use of integrative psychotechnics for recreational purposes is justified. The proposed program of wellness psychotechnology "Relaxation-Imagination-Comfort" ("RIC") is one of the integrative psychotechnologies, based on the synthesis of methods of concentrative relaxation, imaginative psychotherapy of the body and includes a set of psychotechnics aimed at ensuring the restoration and preservation of the full functioning of the body, based on means of internalization of the Bodily locus of control, relaxation and self-regulation based on feedback from the Bodily-Self. The RIC program is based on the principle of gradual mental deepening and expansion of the practice of mental integration and involves the consistent implementation of the preparatory stage, three main (relaxation, awareness, imagination) stages and the final stage. Based on a synthesis of empirical data, it is shown that, as a result of the use of health psychotechnology ("RIC"), positive dynamics of subjective assessment of health and well-being, a decrease in the intensity of somatic complaints, harmonization of dominant psycho-emotional states, the level of verbalization of the Bodily-Self and emotional acceptance of one's body were revealed, which characterizes the potential for self-healing and maintaining the psychosomatic balance of the individual.
\end{abstract}

KEYWORDS: imaginative body psychotherapy, wellness psychotechnology, Bodily locus of control, relaxation, self-regulation.

Problem statement. The problem of health, ways of its preservation and restoration is extremely acute in the modern world in general, and in Ukraine in particular. Recently, science has relied on a holistic approach to the study of man in the unity of its biological, social, physical and spiritual. The expansion of synergetic ideas about a person as a complex system leads to increased attention to psychosomatic issues. The attitude of a modern person towards its health is paradoxical. Health takes a high place among life values, at the same time, health acts as an exploited resource, a means of survival in the current economic and social reality of society (Zhuravlyova, 2014, Berezina \& Verzhibok,
2015). In modern Ukraine, there is an acute problem of using psychological technologies for healing, stimulation of a conscious attitude to one's health, which is caused by the contradiction between the high objective requirements of society for health and the low level of respect for one's body, a healthy culture, and a general deterioration in the health of citizens. Decrease in the level of health is considered today as a social, general cultural problem (Ananyev, 2006, 2007, Nikiforov, 2011).

Analysis of recent publications. The diversity of scientific approaches to health fits into three main explanatory models - the model of coherence, the model of adaptation and the model of spiritual and 
creative potential (Vasilieva \& Filatov, 2005). The model of consistency with the ideal of health emphasizes the harmony of various beginnings in man. The adaptation model characterizes the orientation towards the norm of the "optimally functioning" individual. The anthropocentric model of revealing spiritual and creative potential emphasizes the capabilities of the person itself. These paradigms describe theoretical ideas about health, define research strategies, organize and apply wellness practices. In the model of coherence, practical recommendations on wellness practices come down to compliance with moderation, choosing a balance of activity-passivity in any sphere of existence and activity due to self-control and selfdiscipline. Improvement in the adaptation model is understood as successful adaptation and comprehensive harmonization of the individual's relationship with the outside world. It is within the framework of this model that methods of psychological impact for health purposes are proposed. So, I. Schultz (1985) linked the healthy functioning of the body with the ability to arbitrarily regulate physiological functions and developed a technique of "autogenic training", his follower H. Liderman considered the overall healing strategy as attitude to maintain the body's internal stability through "Autogenous immersion" (Liderman, 2000). The main to the anthropocentric model of health is the idea of the higher (spiritual) mission of man. The existential, humanistic, transpersonal schools of psychology operate with modifications of precisely anthropocentric concepts of health. Improvement in this model is considered in the context of revealing the potential of personality development, integration of the personality and its openness to new experience.

Various definitions of health make it possible to classify this category as systemic, multi-level and multifaceted. Generalized descriptions consider health as a state of optimal life activity of the subject, the completeness of the manifestation of its vitality, the comprehensiveness and durability of social activity and the harmonious development of personality. L.V. Kulikov considers the sanogenic potential of the individual as the main psychological mechanisms for ensuring and maintaining health , which includes stability and harmony of the individual, personal psychohygiene (Kulikov, 2004). Moreover, significant subjective well-being acts as subjective criterion of health, which determines the characteristics of the dominant psycho-emotional state and satisfaction with life. V.A. Ananyev (Ananyev, 2006) describes the potential of health and its components (varieties) as - potentials of the mind (the ability to know), will (the ability to set and achieve goals), feelings (emotional competence), the body (awareness of physicality, understanding of "body language" ), social potential (social competence), creative potential and spiritual potential (the ability to embody the highest values).

The salutogenic theory of A. Antonovsky presents a special version of understanding health, the mechanisms of its maintenance and restoration (Antonovsky, 1990, 1996). Since health and disease form the outermost points of the continuum, a person's state of health includes many transitional (intermediate) states. Approaching the pole of health is accompanied by the formation of a special feeling - sense of coherence, which is a systemic salutogenetic orientation of a person in itself and in the world. Sense of coherence includes three components: 1) comprehensibility - confidence that the stimuli coming from external and internal sources of experience in the process of life are structured, predictable and interpretable; 2) controllability is related to the extent to which the individual considers the resources available to him or she as sufficient to meet the requirements of incentives; 3) meaningfulness is related to the degree to which a person experiences an emotional excitement that life makes sense, how much he or she feels that problems and requirements are worth investing. A. Antonovsky points out three ways of the effect of sense of coherence on health: 1) the positive effect of sense of coherence through psychosomatic mechanisms on the functioning of the endocrine and immune systems, which helps maintain homeostasis in the body; 2) people with a high sense of coherence are more motivated to avoid situations or activities that threaten their health, and to actively engage in activities that contribute to maintaining health; 3) sense of coherence affects cognitive stress assessment processes (Antonovsky, 1996).

Modern psychotherapy and medicine increasingly face their own limitations on helping to improve the personality. Medication methods are not able to cope with their tasks due to the duration of treatment, possible getting used to the intervention of the therapist and focus on curing only the external, physical manifestations of the disease. Therefore, at present, it is quite relevant and logical to search for 
new methods of healing a person, focused on the formation of a conscious, value-based attitude of a person to their health and a qualitatively new semantic attitude not to "get rid of an illness", but to "maintain a healthy state of the body and spirit".

During the long history of its existence mankind has accumulated great experience of using physical and psychological techniques not only in prevention and treatment of diseases, but also for harmonious improvement of personality, and improvement of quality of life in general. The most developed is the problem of techniques and practices of mental selfregulation, representing the effects on themselves using words and images to manage activities and mental states. The methods of mental self-regulation are complex and involve the inclusion of various areas of the psyche: sensory, perceptual, intellectual, emotional, volitional, etc. Verbal and non-verbal methods of self-regulation are distinguished. Verbal include: self-hypnosis, self-belief, self-analysis, analysis of the situation; non-verbal - breathing exercises, physical exercises, switching attention, plot representations (visualization), meditation (Ananyev, 2000, Prokhorov, 2006). Examples of the use of self-regulation methods in medical and psychological practice are ideomotor training, psycho-muscular training, Jacobson's Relaxation Technique, Schultz autogenous training, etc. (Prokhorov, 2005, Pavlova \& Sergienko, 2016).

The efficiency of application of self-regulation methods for recreational purposes is shown in the works of E.A. Kulakova, L.L. Artamonova, Y.P. Denisenko et al. E. A. Kulakova shows the effectiveness of the prevention of fatigue through self-regulation, in particular meditation (Kulakova, 1991). One of the signs of self-regulation is the ability to control the activity of the nervous system. This ability can be developed with the help of special breathing exercises. Active and passive, static and dynamic breathing exercises with expiratory activation should be used (Artamonova, Panfilov \& Borisov, 2014). According to Y. P. Denisenko and co-authors (Denisenko, Vysochin \& Yatsenko, 2012), significant changes in the state of the respiratory system occur during relaxation of the respiratory muscles, which, according to the electroencephalogram, leads to a significant decrease in the flow of afferent and efferent pulses, accompanied by the appearance of a trophotropic state, decrease in anxiety, decrease in the level of physiological and psychological reactions to stressful effects. In addition, after relaxation in the wakeful state with active cortical activity, concentration increases. Thus, relaxation can be used to prevent, correct, and eliminate negative psychoemotional states and increase the adaptive capacity of the body.

Methods of mental integration became famous in the late 1980s. They are based on ancient and new, eastern and western techniques of integrative influence on a person, the result of which is a general mental and somatic healing, harmonization of the emotional sphere, intensive development of latent abilities, actualization of creative potential, and increase of mental energy resources. Experimental studies of I.S. Shemet show that the methods of integration of psyche can qualitatively increase the level of human health and abilities. The idea of reuniting a person with non-integrated parts of its personality is actively used to restore health, primarily psychological, in the practice of psychotherapy, psychosomatic medicine and psychology (Shemet, 2004).

Thus, the use of health-improving psychotechnologies can be proposed as a means of preserving health, which are based on the mechanisms of integration of the psyche, the development of a sense of coherence and autopsychological competence as the main factor in activating a person's personal sanogenic potential.

Aim of the study is to determine the dynamics of verbalization of bodily and subjective assessment of the state of health as a result of the application of health psychotechnologies RIC (relaxationimagination-comfort).

Statement of the main material. By the term "Improving psychotechnology" we mean a set of psychotechnics aimed at ensuring the restoration and preservation of the full functioning of the body, based on the means of internalizing the body locus of control, relaxation and self-regulation based on feedback from the Bodily "Self". The bodily locus of control is seen as a tendency to attribute the causes of what happens to the body in the areas of physical activity and health, alimentary and sexual behavior to external or internal factors. At the same time, the internal bodily locus of control is a tendency to see the reasons for what is happening with the body, the tendency to accept responsibility for one's state and the functioning of one's own body. Relaxation is understood as the process of acquiring equilibrium in the body system, as a psychosomatic unity, by 
relieving tension in the body and achieving a state of calm. Self-regulation based on feedback with the bodily self is a characteristic of psychosomatic competence, is based on sensory and symbolic forms of feedback and ensures the functioning of the body as a system, the activity of which is dominated by the equilibrium vector (Khomulenko, 2017).

Wellness psychotechnology cover the inner space of a person in the unity of the conscious and unconscious, as well as in the unity of the intra- and interpsychic realities that lead the psyche to greater integrity. With the help of modern psychotechnologies, the following correctionaldeveloping and health-improving tasks of applied psychology can be solved: 1) psychological assistance to people in need of a total improvement of the body and psyche; 2) drug-free therapy of psychosomatic disorders and normalization of borderline conditions; 3) the mobilization and actualization of the reserve capabilities of the psyche; 4) increasing stress resistance, performance and adaptability of the psyche and body of the individual; 5) training in setting up the optimal mode of arbitrary bodily self-regulation; 6) self-knowledge and self-improvement of a person; 7) strengthening the emotional and volitional potential of the individual in the fight against bad habits of an unhealthy lifestyle; 8) expansion of the sphere of consciousness.

The study involved 32 students of H.S. Skovoroda Kharkiv National Pedagogical University from 18 to 27 years old, including 29 female subjects and 3 male subjects. The selection of program participants was carried out on the basis of criteria for recognizing the need for the use of healthimproving psychotechnologies, interest and voluntary participation. Six working groups of 5-6 people each were formed, which was due to recommendations regarding the quantitative composition for the group form of conducting imaginative body therapy. In addition, the group form of psychotherapeutic influences has several advantages, which are: 1) group experience and the similarity of the experienced feelings counteracts the exclusion of a person, unproductive closure in oneself; 2) the ability to receive feedback and mutual support; 3) the opportunity in the conditions of psychological safety to analyze the patterns of communication and behavior that are not obvious in everyday situations; 4) the group facilitates the processes of self-disclosure, self-exploration, self- knowledge and experimentation with new forms and styles of relationships; 5) saving of time (Rudestam, 2001).

The research involved the application of a classic "before-after" experiment with psychodiagnostics at the beginning and at the end of the implementation of a complex of techniques of imaginative body therapy. The following were selected as the main psychodiagnostic techniques:

1. Health self-assessment questionnaire A. Ware, C. Wright, M. Snyder, which allows to diagnose a subjective assessment of health and well-being (cited by Shurygina, 2009).

2. Giessen Subjective Complaints List (GBB), adapted by B.A. Ababkov, S.M. Babin, G.L. Isurina. The questionnaire reveals the intensity of emotionally colored complaints about physical wellbeing, and also allows to diagnose certain factors of malaise - exhaustion, stomach complaints (epigastric syndrome), pain in various parts of the body, heart complaints. We used the data of the "Pressure" (intensity) complaints scale, which characterizes the overall intensity of subjective ailments (cited by Raygorodsky, 1998).

3. The methodology for determining the dominant state (Kulikov, 2003), which allows to diagnose features of the characteristics of the personal level of mental stable (dominant) states: "active - passive attitude to life situation", "vigor-despondency", "high tone - low", " looseness-tension "," calmness anxiety", "stability - instability of emotional tone ", “ satisfaction - dissatisfaction with life ". In addition, the technique was used to describe the level and quality of psychological well-being. In the "active passive attitude to life situation" scale, the higher the score on the scale, the more pronounced the positive pole of the trait being measured. On the scales "vivacity-despondency", "tone high - low", "looseness-tension", "calmness - anxiety", "stability - instability of emotional tone", "satisfaction dissatisfaction with life" - the higher the indicator on the scale, the less the positive pole of the measured characteristic is expressed.

4. The technique of "verbalization of the bodily self" was used to assess the integral indicator of psychosomatic competence and the valency of the emotional attitude to your body (Khomulenko \& Kramchenkova, 2016).

Methods of statistical processing of empirical data included analysis of the significance of differences using the Paired Sample T-Test. 
The program of health-improving psychotechnology "relaxation-imagination-comfort" (RIC) is one of the integrative psychotechnologies and is based on the synthesis of methods of concentrative relaxation (Anita Wilda-Kiesel, 2004), and magnetic psychotherapy of the body (Loesch, 2008).

Imaginative body psychotherapy $(\operatorname{ImKP})$ is a modern direction of psychosomatic psychotherapy, which includes a set of exercises for relaxation, healing communication with one's own body and imaginative exercises, which are based on figurative memory and ideas (Loesch, 2008). In Germany, this direction of psychotherapy is a specialization of catatymo-imaginative psychotherapy. Imaginative body psychotherapy has been shown to be highly effective in working with different groups of psychosomatic and severe somatic diseases (oncology, autoimmune diseases). Its author, Dr. W. Loesch, calls his method as healing communication with the body. The main work in ImKP is based on the use of imagination and attention to your body. At the same time, the focus of attention is directed to the sensation of your body, without any bodily touch to it. ImKP methodically relies on concentrative relaxation, symbol drama (Obukhov, 1997), and auto-training. An important condition for ImKP is the creation of an internal safe space, which allows patients to relax and find resources for further work. Further, the work is carried out in an individual form, when the patient, with the help of a psychotherapist, gradually comes to the creation of his own unique healing strategy. Concentrating calm attention on the sensations of its body for a long time, the patient begins to present images that correspond to the signals of the body. The image that appears to be a symbol of what is happening in the body.

The Concentrative Relaxation Method (Konzentrative Entspannung, KoE) method was created in Germany in the 60s of the XX century by Anita Wilda-Kiesel based on many other techniques of working with conscious body relaxation and, primarily, was used in sports as an effective method that contributes to a significant improvement of Olympic results among athletes of the German Democratic Republic (Wilda-Kiesel, 2004). Later, this method became widespread for working with psychosomatic diseases, for physical rehabilitation after injuries, for working with children and adolescents in order to achieve a stable state of relaxation, calmness and more conscious perception of the various sensations of your body. This method is based on a clear and consistent pattern of focus and concentration on specific parts of your body.

In the process of implementing the program of health-improving psychotechnology RIC (relaxation-imagination-comfort), positive changes were achieved due to the psychological effects of self-diagnosis and reflection of the leading attitudes in the field of bodily, increase of sensitivity, development of the attitude towards the comprehensiveness of perception, integrity and interconnection of bodily, cognitive and emotional phenomena of the inner world of a person, the formation of mental self-regulation skills of the body, as well as the psychotherapeutic effects of conscious integration, knowingness and unconscious in the unity of intra- and interpsychic realities.

The program of improving psychotechnology RIC consisted of preparatory, three main and final stages. The implementation of the program of healthimproving psychotechnology RIC (relaxationimagination-comfort) is designed for 4 months and is based on the principle of gradual mental deepening and expansion of psychotherapeutic practice. Table 1 shows the general organization of the program of health-improving psychotechnology "RIC".

The preparatory phase was devoted to motivating participants, actualization of their leading needs in connection with the program's purpose, informing about the program's content, the format for further work, as well as the initial psychodiagnostics of the subjective characteristics of health, well-being, stable psycho-emotional states and the verbalization of the "bodily self".

The first of the main stages "Relaxation" is devoted to mastering the technique of "concentrative relaxation". At this stage, the program participants had to direct their attention to their own body and the processes that take place in it for the development of dialogue with their own "Bodily Self". Relaxation in the form of external and internal calming occurs as a result of benevolent and positively directed attention to the body (Loesch, 2008). Participants were asked to feel those parts of the body that are in contact with the surface on which the person lies: the surface itself, the distance to it of various parts of the body, especially contact with the surface. Then there is a gradual, step-by-step perception of one's body: differentiated perception and body sensation with the aim of influencing the stress-relaxation ratio and 
achieving the final result through: step-by-step training; perception of the surface with which the body is in contact; perception of tension. Then it is proposed to feel and realize your body, as well as everything that happens in it (for example, the rhythm of breathing, micro-movement of the joints, posture and body position). The following is an active influence on the phases of tension and muscle relaxation. Conscious relaxation of pinched, tense muscle groups.

Table 1

Scheme of organization of the program of health-improving psychotechnology RIC

\begin{tabular}{|c|c|c|c|c|}
\hline \multirow{2}{*}{\multicolumn{2}{|c|}{$\begin{array}{l}\text { Program stage } \\
\text { Preparatory }\end{array}$}} & \multirow{2}{*}{$\begin{array}{l}\text { Content of the work } \\
\begin{array}{l}\text { Motivation, informing, psycho- } \\
\text { diagnostics }\end{array}\end{array}$} & \multirow{3}{*}{$\begin{array}{l}\text { Forms of work } \\
\text { Group } \\
\text { Group }\end{array}$} & \multirow{2}{*}{$\begin{array}{l}\text { Time frame } \\
1 \text { meeting }(1,5 \\
\text { hour) }\end{array}$} \\
\hline & & & & \\
\hline \multirow{7}{*}{ Main } & \multirow{2}{*}{ Relaxation } & \multirow{2}{*}{$\begin{array}{l}\text { Concentrative Relaxation Practice. } \\
\text { State Reflection }\end{array}$} & & $\begin{array}{l}8 \text { meetings of } 30 \\
\text { minutes each }(4 \\
\text { weeks })\end{array}$ \\
\hline & & & $\begin{array}{l}\text { Separate practice of } \\
\text { concentrative } \\
\text { relaxation }\end{array}$ & $\begin{array}{l}\text { Daily for } 20-30 \\
\text { minutes }\end{array}$ \\
\hline & \multirow{2}{*}{ Awareness } & \multirow{2}{*}{$\begin{array}{l}\text { Acquaintance with the structure and } \\
\text { features and functioning of organs and } \\
\text { systems of the body. } \\
\text { Concentrative relaxation practice }\end{array}$} & Group & $\begin{array}{l}4 \text { meetings of } 40 \\
\text { min. ( } 2 \text { weeks })\end{array}$ \\
\hline & & & $\begin{array}{l}\text { Separate practice of } \\
\text { concentrative } \\
\text { relaxation }\end{array}$ & $\begin{array}{l}\text { Daily for } 20-30 \\
\text { minutes }\end{array}$ \\
\hline & \multirow{3}{*}{ Imagination } & \multirow{3}{*}{$\begin{array}{l}\text { The practice of concentrative } \\
\text { relaxation.Internal observation of } \\
\text { images in a given direction. } \\
\text { Work with a picture of imaginations. } \\
\text { Reflection of states and figures }\end{array}$} & Group & $\begin{array}{l}8 \text { meetings of } 1.5 \\
\text { hours ( } 4 \text { weeks) }\end{array}$ \\
\hline & & & $\begin{array}{l}\text { Individual work with } \\
\text { a psychologist }\end{array}$ & $\begin{array}{l}8 \text { meetings for } 1 \\
\text { hour ( } 4 \text { weeks) }\end{array}$ \\
\hline & & & $\begin{array}{l}\text { Separate practice of } \\
\text { concentrative } \\
\text { relaxation }\end{array}$ & $\begin{array}{l}\text { Daily for } 20-30 \\
\text { minutes }\end{array}$ \\
\hline \multicolumn{2}{|l|}{ Final } & Reflection of results, psychodiagnostics & Group & $\begin{array}{l}1 \text { meeting }(1,5 \\
\text { hour })\end{array}$ \\
\hline
\end{tabular}

Concentrative relaxation was carried out in a prone position under the guidance of a leading psychologist. The group members lie on the floor, on special sports mats, which contributes to a better focus on the sensations of their own body. Each of the participants should consistently direct attention to those parts of the body that the host psychologist is talking about. An important condition for working in this method is the need to pronounce your feelings aloud.
The host psychologist offers to feel and verbalize each of the participants the following sequence, in which points 6 and 9 are the author's refinement, which includes elements of the Taoist practice of internal alchemy, and are tested in the context of the effect of the relaxation effect.

1. Lie down as comfortably as possible and close your eyes. All external sounds gradually fade into the background and you are increasingly focusing 
attention on yourself and on your body. As you fix attention on the body, it begins to relax.

2. Where do you most feel the contact of your body with the support on which you are located? Please name all zones. (For example: nape, shoulders, buttocks, lower legs, heels).

3. Where do you most feel the space between your body and the support on which you are located? Please name all zones. (For example: neck, lower back, area under the knees, ankles). Please imagine a material that is pleasant for you (sand, a pillow), with which you would like to fill the space between the zones of your body and the support.

4. Focus on your right foot. How is it located? Does it lie flat or slightly bent? Where do you feel the areas of greatest touch of your right foot to the support? Where do you feel the distance between your right foot and support? Where do the socks of your right foot look? How do you feel your foot? Do you feel all the fingers on the right foot the same way, or are there any that you feel better than others? About what area does the heel occupy, what shape is this area, how many approximately square centimeters? What area does the tibia occupy, what shape is this area, how many approximately square centimeters? What area is the buttocks, what shape is this area, how many approximately square centimeters?

5. Focus on your left foot ..... (Procedure similar to paragraph 4)

6. Which leg is warmer, which is less warm ... (heavy, long, light, wet, dense, transparent). Which leg is more relaxed? (For example, the left) Make the right foot as relaxed as the left.

7. Focus on your right hand, how is it located? How far is it from the body? Is it even or slightly bent? Where do you feel the areas of greatest touch of your right hand to the support? Where do you feel the distance between your right hand and the support? How do you feel your palm? Fingers on the right hand? Is there a finger or fingers that you feel better than others? What would you like to put in the palm of your hand?

8. Focus on your left hand ... (Procedure similar to paragraph 7).

9. Which hand is warmer, which is less warm ... (heavy, long, light, wet, dense, transparent)? Which arm is more relaxed? (For example, the left) Make the right hand as relaxed as the left.

10. Focus on your back. Where do you feel the areas of greatest touch of your back to the support?
Where do you feel the distance between your back and support?

11. Focus on your head. How do you feel the back of your head? Approximately, what area does the occiput occupy, what shape is this area, how many approximately square centimeters?

12. Once again, go through the attention throughout the body, relax and as if dissolve all the tense zones and parts. Which part of the body is most relaxed (for example, the left leg). Which part of the body is the least relaxed (for example, the right arm)? Make your left foot as relaxed as your right arm. Then, gradually activate yourself and open your eyes. Stretch smoothly, do not rush to get up.

The result of mastering the technique of concentrative relaxation is a more conscious and full sensation of your body and the achievement of persistent psychosomatic relaxation. At this stage, the participants received the task of a daily 20-30 minute practice of concentrated relaxation at home. Each meeting began and ended with a reflection of the conditions associated with the practice of concentrative relaxation.

At the "Awareness" stage, the task of informing about the structure and functioning of the main organs and systems of the human body was solved. To solve this problem, 4 classes were organized devoted to the formation of knowledge about the structure and functions of the autonomic nervous system, heart, thymus and spine. At this stage, an independent daily 20-30 minute practice of concentrative relaxation at home was maintained.

At the "Imagination" stage, against the background of the practice of concentrative relaxation, participants under the guidance of a leading psychologist were offered imaginative tasks aimed at consciously presenting certain topics. Imaginative exercises were implemented as follows. The host psychologist suggested that the participants present an image on a specific given topic. After each presentation of the image, the participants in the group were asked to evaluate the brightness, emotional coloring, dynamism, image on a given topic, and then draw a picture of the imagination with a non-dominant hand. At the disposal of the group members were a variety of materials for drawing: pencils, paints, colored chalk, various paper sizes (A3, A4, A5). After drawing, each member of the group talks about his image, which he presented and demonstrates his drawing to the leading psychologist and other participants, if desired. 
During the first 4 meetings, it was necessary to present the heart, thymus, and spine as a plant as imaginative tasks. For example, "Imagine your heart as a plant that has everything for good growth and development. What is this plant? In what area does it grow? What is its root, what is the earth near it? What leaves, stem, petals? Does the plant smell? Try in your imagination to touch the plant. What do you feel? Imagine what this plant needs for good growth and development. Imagine how a plant is lit by the sun, that you look after it - water it, fertilize it. " Further, similar imaginations were performed with the thymus and spine. The following imaginations include introducing organs and washing them with fresh arterial blood. For example, "Imagine your heart as it may look. Imagine arterial blood saturated with oxygen and important nutrients entering the heart. The heart, all its parts, as it were, are washed with fresh, renewed blood, and all unnecessary metabolic products, toxins, etc., are washed and left with venous blood. Imagine how this happens ... ". Imaginations finalising with a pattern of images with a nondominant hand.

The next 4 meetings are distinguished by the addition of an imagination of a place of inner comfort and balance, which also ends with a drawing with a non-dominant hand. The host psychologist tells the participants: "Imagine the place of your inner comfort and balance. It can be any place that you have ever seen, or which will now draw your imagination. Maybe this is the place you once dreamed about. What is the weather like in this place now? What season? What smells are there right now? Are there any sounds here? What exactly in this place makes it calm and protected for you?".

Imagination of an internal adviser, which is included in the authentic version of the method of imaginative body psychotherapy (ImKP), can be used with the use of RIK psychotechnology for psychotherapeutic or therapeutic purposes.

It is very important that the person who represents the image verbalizes its feelings and mood, so each meeting ended with a reflection of the imaginations and drawings. In this psychotechnology, the method of silent presentation of images was used: when each of the group members presented their image in silence, and only then, after its completion, told the leading psychologist and group about what they imagined and about their feelings during the imagination. In this case, the leading psychologist pays attention to the following questions: "What was the most pleasant in the image? Did you manage to imagine the image? How clear was it? Was it possible during the performance to experience different modalities of perception: colors, sounds, smells, touches, tastes? What was the most pleasant during the presentation of the image? Perhaps something like less or evoked negative emotions? What was unexpected, what surprised most of all? "It is proposed to remember those positive emotions that a person felt being in the image, and, if necessary, recall this image as a technique of self-regulation of the psycho-emotional state.

In addition, at the "Imagination" stage, participants were offered individual work with a psychologist once a week, dedicated to performing imaginations, demonstrating and discussing drawings, and working with psycho-emotional states.

The final "Reflexive" stage is aimed at understanding and fixing the results of participation in the "RIC", as well as actualization the attitude of the active use of acquired knowledge, skills in the future. Fixing the positive dynamics and detailing the acquired abilities as a result of psychodiagnostics and discussing its results allows participants to realize their own achievements as a result of the "RIC". As a result of such a group discussion, participants come to the conclusion that the acquired knowledge, skills, and abilities will help in the development of selfregulation and the improvement of their own body, and the ability to stimulate their own productive activities.

The effectiveness of health-improving psychotechnology "RIC" was tested on the basis of data on the dynamics of subjective health characteristics obtained in a control study, the results of which are displayed below (Table 2).

As the results show (Table 2), self-assessment of own state of health, both at the preliminary and at the final stages of the study, does not exceed standard values for people who do not suffer from severe chronic diseases (69 points). At the same time, after the implementation of the healthimproving psychotechnology "RIC", a statistically significant $(\mathrm{t}=-4.18 ; \mathrm{p}<0,0005)$ improvement in assessing one's health and physical condition is noted. 
Table 2

Dynamics of indicators of health self-esteem (physical well-being) after the implementation of health-improving psychotechnology RIC

\begin{tabular}{|c|c|c|c|c|}
\hline \multirow{2}{*}{ Parameters } & \multicolumn{2}{|c|}{ Average values of indicators $(\mathrm{M} \pm \sigma)$} & \multirow{2}{*}{$\mathrm{t}$ - criterion } & $\mathrm{p}$ \\
\cline { 2 - 4 } & $\begin{array}{c}\text { Before the } \\
\text { implementation of } \\
\text { psychotechnology }\end{array}$ & $\begin{array}{c}\text { After the } \\
\text { implementation of } \\
\text { psychotechnology }\end{array}$ & $-4,18$ & $<0,0005$ \\
\hline $\begin{array}{c}\text { Assessment of } \\
\text { health and well- } \\
\text { being }\end{array}$ & $51,72 \pm 13,86$ & $43,06 \pm 9,82$ & $-7,15$ & $<0,00001$ \\
\hline $\begin{array}{c}\text { Intensity of } \\
\text { subjective } \\
\text { ailments }\end{array}$ & $30,31 \pm 7,67$ & $23,44 \pm 9,21$ & & \\
\hline
\end{tabular}

The data obtained indicate a decrease in the level of anxiety for the state of own physical health, and an increase in satisfaction with somatic well-being.

The negative dynamics of the intensity of physical ailments $(\mathrm{t}=-7.15 ; \mathrm{p}<0.00001)$ is shown, which is characterized by a decrease in subjective anxiety about their ailments, an improvement in the emotional stereotype of perception of organic conditions, possible painful or unpleasant sensations.

The subjective well-being of a person as a characteristic of health and psychosomatic status is directly related to the dominant mental state. The results of a study of the dynamics of dominant psychoemotional states are presented in Table 3.

Table 3

\section{Dynamics of indicators of the dominant psychoemotional state after the implementation of} recreational psychotechnology RIC

\begin{tabular}{|c|c|c|c|c|}
\hline \multirow{2}{*}{ Parameters } & \multicolumn{2}{|c|}{ Average values of indicators $(\mathrm{M} \pm \sigma)$} & \multirow{2}{*}{} \\
\cline { 2 - 3 } & $\begin{array}{c}\text { Before the } \\
\text { implementation of } \\
\text { psychotechnology }\end{array}$ & $\begin{array}{c}\text { After the } \\
\text { implementation of } \\
\text { psychotechnology }\end{array}$ & \multirow{t}{*}{ - criterion } & \\
\hline $\begin{array}{c}\text { Active - passive attitude } \\
\text { to life situation }\end{array}$ & $40,97 \pm 8,09$ & $42,44 \pm 8,45$ & 1,66 & $>0,05$ \\
\hline $\begin{array}{c}\text { Cheerfulness - } \\
\text { despondency }\end{array}$ & $21,47 \pm 6,26$ & $18,09 \pm 4,75$ & $-3,19$ & $<0,005$ \\
\hline Tone high - low & $28,88 \pm 8,32$ & $21,59 \pm 8,23$ & $-5,35$ & $<0,00001$ \\
\hline Relaxedness-stress & $24,28 \pm 6,34$ & $21,22 \pm 3,01$ & $-2,53$ & $<0,05$ \\
\hline Calm - anxiety & $25,69 \pm 7,74$ & $19,06 \pm 4,15$ & $-6,42$ & $<0,00001$ \\
\hline $\begin{array}{c}\text { Stability - instability of } \\
\text { emotional tone }\end{array}$ & $23,91 \pm 9,96$ & $22,50 \pm 9,61$ & $-0,65$ & $>0,05$ \\
\hline $\begin{array}{c}\text { Satisfaction - } \\
\text { dissatisfaction with life }\end{array}$ & $32,31 \pm 11,58$ & $26,06 \pm 8,42$ & $-3,51$ & $<0,005$ \\
\hline
\end{tabular}

As the obtained data show, after the implementation of the RIK psychotechnology, there was a positive dynamics in the dominant psychoemotional states of the participants in terms of cheerfulness - despondency $(\mathrm{t}=-3.19 ; \mathrm{p}<0.005)$, tone high - low $(\mathrm{t}=-5.35 ; \mathrm{p}<0.00001)$, relaxedness-stress $(\mathrm{t}=-2.53 ; \mathrm{p}<0.05)$, calm anxiety $(\mathrm{t}=-6.42 ; \mathrm{p}<0.00001)$, satisfaction dissatisfaction with life $(\mathrm{t}=-3,51 ; \mathrm{p}<0.005)$. Thus, after the implementation of "RIC" there was an increase in cheerfulness, an expansion of interests and expectations of positive events in the future, a positive psycho-emotional background increased, which contributes to the desire to act. An increase in tone characterizes an increase in the subjective sensation of compilation, a supply of strength, energy, a decrease in fatigue, inertia, greater efficiency, as well as an increase in the likelihood of a stenic reaction to difficulties. The decrease in tension in the structure of dominant psycho- 
emotional states shows that participants more perceive the desired goals as achievable. Their emotional acuity and rejection of negative life situations decreased, the severity of the desire to master the situation, intensively perform the necessary transformations decreased. The most significant changes in indicators on the scale of calm-anxiety characterize a significant decrease in anxiety, the acquisition of greater confidence in their abilities and capabilities. This indicator is especially important in the context of this study, since the experience of anxiety enhances the subjective value of emotiogenic stimuli, their negative impact on health. An increase in life satisfaction indicators indicates an increase in the sense of responsibility for oneself in one's life choices, and about a willingness to overcome difficulties in self-realization, which leads to a positive assessment of personal success. The foregoing allows us to state the harmonization of stable psycho-emotional states after the implementation of "RIC".

Indicators of the dynamics of verbalization of "Bodily Self" after the implementation of the healthimproving psychotechnology "RIC" are presented in Table 4.

Table 4

The dynamics of indicators of verbalization of "Bodily Self" after the implementation of RIC health-improving psychotechnology

\begin{tabular}{|c|c|c|c|c|}
\hline \multirow{2}{*}{ Parameters } & \multicolumn{2}{|c|}{ Average values of indicators $(\mathrm{M} \pm \sigma)$} & \multirow{2}{*}{$\mathrm{t}$ - criterion } & $\mathrm{p}$ \\
\cline { 2 - 4 } & $\begin{array}{c}\text { Before the } \\
\text { implementation of } \\
\text { psychotechnology }\end{array}$ & $\begin{array}{c}\text { After the } \\
\text { implementation of } \\
\text { psychotechnology }\end{array}$ & 5,10 & $<0,00005$ \\
\hline $\begin{array}{c}\text { The level of } \\
\text { verbalization of } \\
\text { "Bodily Self" }\end{array}$ & $34,56 \pm 10,55$ & $47,69 \pm 9,30$ & 4,83 & $<0,00005$ \\
\hline $\begin{array}{c}\text { The valency of the } \\
\text { verbalization of } \\
\text { "Bodily Self" }\end{array}$ & $0,06 \pm 0,37$ & $0,36 \pm 0,20$ & & \\
\hline
\end{tabular}

The results of the study show a significant increase in the level of verbalization $(t=5.10$; $\mathrm{p}<0.00005)$ as an integral indicator of the system of the cognitive component of the bodily self, reflexivity in the body, which is associated with the adoption of own body as a component of the whole organism, and determines the basis for selfregulation in an internal dialogue with the "Bodily Self". The analysis of the dynamics of the valency of the verbalization of "Bodily Self" indicates the transformation of a neutral emotional attitude to own body into a positive one $(\mathrm{t}=4.83 ; \mathrm{p}<0.00005)$. A positive emotional-value attitude to the body characterizes the acceptance and predominantly positive feelings that the participants experience in relation to their body.

Thus, the integrative nature of recreational psychotechnology "RIC" contributes to the unity of the cognitive and emotional-value components of the "Bodily Self", which contributes to the normal functioning of the body due to the completeness of the content of the cognitive component, positivity and adequacy of the content of the emotional-value component and reflexive regulation. The data obtained in the study speak in favor of the possibility of using RIC psychotechnology in order to maintain psychosomatic balance, optimize the individual's internal reserves in self-healing and psychological harmonization. Since psychosomatic disorders (functional syndromes and psychosomatoses) as defined by D.S. Rozhdestvensky is the ultimate manifestation of an individual's life style brought to an existential absurdity (Rozhdestvensky, 2009), the psychological integration on which RIC psychotechnology is built allows emphasizing important aspects of the relationship between mental and physical and balancing the psychoemotional style of responding to one's physical states, as one from the manifestations of life style. In other words, RIC psychotechnology is not focused on treatment, but on ensuring the renewal and preservation of the full functioning of the body through internalization of the body locus of control, relaxation, and self-regulation based on feedback from the "Bodily Self". 
The results obtained are consistent with the data of A.S. Zakharevich on the effectiveness of the use of recreational respiratory psychotechnologies for improving the mechanisms of mental self-regulation of states, development and mobilization of the reserve capabilities of the body and psyche. In particular, the author found that the use of respiratory psychotechnologies improves the balance of psychological qualities, reduces the level of painful conditions and mental tension, increases the level of general and private sensitivity, helps to reveal the person's internal psychological resources, the adequacy of self-esteem and satisfaction with their position in society (Zakharevich, 2003).

The results of the study also confirm the data of G.E. Pazekova on the positive impact of ideational technologies for the healing and harmonization of personality. In the work of G.E. Pazekova shows the relationship of work with prototypes and the functional state of the personality, as well as its impact on the dynamics of all three components of health (physical, mental, spiritual). In particular, the effects of normalizing and supplying blood to the hemispheres of the brain, improving the subjective attitude to one's experience, to one's personal time, to creativity, to own health, to own body, as well as optimizing self-esteem of well-being, activity, and mood (Pazekova, 2011) were found.

Conclusions. The presented program of health psychotechnology "RIC" includes a set of techniques of imaginative body psychotherapy according to $\mathrm{W}$. Loesch and is based on the principle of gradual mental deepening and expansion of the practice of mental integration. The program involves the consistent implementation of the preparatory, three main (relaxation, awareness, imagination) and the final stages. As a result of the application of the health-improving psychotechnology "RIC", a positive dynamics of the subjective assessment of health and well-being, a decrease in the intensity of somatic complaints, harmonization of the dominant psycho-emotional states, the level of verbalization of the "bodily Self" and the emotional acceptance of own body, which characterizes the potential for self-healing and maintaining the psychosomatic balance of the personality revealed.The prospect of further research may be the study of the bodily locus of control in the context of psychosomatic phenomena of normal functioning, functional syndromes and psychosomatoses.

\section{REFERENCES}

Ananyev, V.A. (2000). Трансово-медитативная саморегуляиия. [Trance-meditative self-regulation]. $\mathrm{SPb}$.: GP «RShATON». (in Russian)

Ananyev, V.A. (2006) Основы психологии здоровья. Книга 1. Концептуальные основы психологии здоровья [The basics of the psychology of health. Book 1. Conceptual foundations of the psychology of health]. SPb.: Rech: (in Russian)

Ananyev, V.A. (2007) Практикум по психологии здоровья: пособие по первичной специфической и неспецифической профилактике [Workshop on Health Psychology: a manual on primary specific and non-specific prevention ]. SPb.: Rech`. (in Russian)

Antonovsky, A. (1990). Personality and health: testing the sense of coherence model. In H.S. Friedman (Ed.). Personality and disease; pp. 155-177. New York: Wiley.

Antonovsky, A. (1996) The salutodenic model as a theory to guide health promotion. Health promotion international, 11(1), 11-18.

Artamonova, L. L., Panfilov, O. P., Borisov, V. V. (2014). Лечебная $и$ адаптивно-оздоровительная физическая культура [Therapeutic and adaptiveimproving physical education] (Ed.) Panfilov, O. P. Moskva: VLADOS-PRESS, 251. (in Russian)

Berezina, V.A., Verzhibok, G.V. (2015) Здоровье как личная и общественная ценность [Health as a personal and social value] Bulletin of the VDU, 5 (89), 116-121. (in Russian)

Denisenko Yu. P., Vysochin Yu. V., Yatsenko L. G. (2012). Стратегии долговременной адаптации к физическим нагрузкам и их влияние на эффективность спортивной деятельности [Strategies for long-term adaptation to physical activity and their impact on the effectiveness of sports activities] Theory and Practice of Physical Culture. 8, 27-30. (in Russian)

Khomulenko, Т.В. (2017). Психотехнологіi саморегуляиї тілесного [Psychotechnology of Bodily self-regulation]. Kharki`v: «Di`sa plyus». (in Ukrainian)

Khomulenko, T.B., Kramchenkova, V.O. (2016). Методика проективної діагностики тілесного Я [Methodology of bodily self projective diagnostics]. Scientific bulletin of KSU. Psychological Sciences Series. 2 (5), 39-45. (in Ukrainian)

Kulakova, E. A. (1991). Приемь саморегуляции в cnopme [Sports self-regulation techniques]/ Moskva: GCzOLIFK. (in Russian)

Kulikov, L.V. (2003). Руководство к методикам диагностики психических состояний, чувств и психологической устойчивости личности. Описание методик, инструкиии по применению [Guide to the methods of diagnosis of mental states, 
feelings and psychological stability of the individual. Description of methods, instructions for use]. SPb.: SPGU. (in Russian)

Kulikov, L.V. (2004). Психогигиена личности. Вопросы психологической устойчивости и психопрофилактики [Personal psycho-hygiene. Issues of psychological stability and psychoprophylaxis]. SPb.: Piter. (in Russian)

Liderman, H. (2000). Аутогенная тренировка [Autogenic training]. Minsk: Popurri. (in Russian)

Loesch, W. (2008) Imaginative Körperpsychotherapie (IKP) als komplementäre Psychotherapiemöglichkeit auch für Krebspatienten. In: Reiners H. (Hrsg.): Neue Versorgungskonzepte in der Onkologie. Eine Tagung der Landesarbeitsgemeinschaft Onkologische Versorgung Brandenburg e. V. (LAGO). Berlin.

Nikiforov, G.S. (Ed.). (2011). Диагностика здоровья: психологический практикум [Diagnostics of health: psychological workshop]. SPb.: Rech`. (in Russian)

Obukhov, Ya. L. (1997). Глубинно-психологический подход в психотерапии психосоматических заболеваний [Deep psychological approach to psychotherapy of psychosomatic diseases]. School of Health, 3, 43-61. (in Russian)

Pavlova, N.S., Sergienko, E.A. (2016) Субъектная и личностная регулячия поведения как проявление индивидуальности человека [Subjective and personal regulation of behavior as a manifestation of a person's individuality. Psychological Journal. 37 (2),43-56. (in Russian)

Pazekova, G. E. (2011). Психологические технологии здоровья: идеационный способ гармонизации личности. [Psychological technologies of health: an ideational way of harmonizing personality]. Scientists notes. Ser. Psychology. Pedagogy, 4, 7982. (in Russian)

Prokhorov, A.O. (2005). Саморегулящия психических состояний: феноменология, механизмы, закономерности [Self-regulation of mental states: phenomenology, mechanisms, patterns]. Moskva: PE`R SE`. (in Russian)

Raygorodsky, D. Ya. (1998) Практическая психодиагностика. Методики и тесты. [Practical psychodiagnostics. Methods and tests]. Samara: Publishing House "Bahrah". (in Russian)

Rozhdestvensky, D.S. (2009) НотоSomaticus. Человек соматический [HomoSomaticus. Somatic man]. Spb.: IP. Sedova E.B. (in Russian)

Rudestam, K. (2001). Групповая психотерапия [Group Psychotherapy]. SPb.: Piter. (in Russian)

Schultz, I. (1985). Аутогенная тренировка [Autogenic training]. Mediczina. (in Russian)

Shemet, I.S. (2004). Интегративные психотехнологии в социальной работе [Integrative Psychotechnologies in Social Work]. Kostroma: KGU. (in Russian)

Shurygina, Yu. Yu. (2009). Научно-практические основы здоровья [Scientific and practical principles of health]. Ulan-Ude`: VSGTU. (in Russian)

Vasilieva, O.S., Filatov F.R. (2005). Психология здоровья. Феномен здоровья в культуре, психологической науке, обыденном сознании [The psychology of health. The phenomenon of health in culture, psychological science, everyday consciousness]. Rostov-na-Donu: Minitajp (in Russian).

Wilda-Kiesel A. (2004) Neurologie, Psychiatrie, Psychotherapeutische Medizin, Kompaktlehrbuch Physiotherapie; Urban \& Fischer, München, Jena.

Zakharevich, A. S. (2003) Оздоровительноразвивающие эффекты дыхательного психотренинга [Improving and developing effects of respiratory psychotraining]. Bulletin of the Baltic Pedagogical Academy, 49, 54-57. (in Russian)

Zhuravlyova, I.V. (Ed.). (2014). Здоровье студентов: соичилогический анализ [Students' Health: A Sociological Analysis]. Moskva: INFRA-M. (in Russian)

\section{КОМПЛЕКС ПРИЙОМІВ ІМАГІНАТИВНОӤ ПСИХОТЕРАПІЇ ТІЛА В ОЗДОРОВЧІЙ ПСИХОТЕХНОЛОГІЇ «РІК»: ЕФЕКТИВНІСТЬ І ОСОБЛИВОСТІ ЗАСТОСУВАННЯ}

Хомуленко Т.Б.

Доктор психологічних наук, професор, завідувач кафедри практичної психології Харківський національний педагогічний університет імені Г. С. Сковороди Крамченкова В.O.

Харківський начіональний педагогічний університет імені Г.С. Сковороди Фоменко К.I.

Кандидат психологічних наук Харківський національний педагогічний університет імені Г.С. Сковороди Я.Л. Обухов-Козаровицкий

Зниження рівня здоров'я розглядається сьогодні як соціальна, загальнокультурна проблема. У сучасній Україні гостро постає проблема використання психологічних технологій оздоровлення, виховання свідомого ставлення до свого здоров'я, що зумовлено протиріччям між досить високими об'єктивними вимогами суспільства до здоров'я, гармонійного розвитку людей і досить низьким рівнем дбайливого ставлення до свого тіла і оздоровчої культури, а також загальним погіршенням здоров'я громадян. Стаття присвячена розробці оздоровчої психотехнології та оцінці їі ефективності на основі дослідження динаміки вербалізації тілесного і суб'єктивної оцінки стану здоров'я в результаті іiі застосування. Представлено узагальнення 
результатів теоретичного аналізу проблеми здоров'я, психологічних механізмів його забезпечення. Обгрунтовано застосування інтеграційних психотехнік в оздоровчих цілях. Запропонована програма оздоровчої психотехнології «Релаксація-імагінація-комфорт» («РІК») являє собою одну з інтеграційних психотехнологій, яка базується на синтезі прийомів концентративного розслаблення, імагнатівної психотерапії тіла і включає комплекс психотехнік, спрямованих на забезпечення відновлення та збереження повноцінного функціонування організму, заснованих на засобах інтерналізації тілесного локусу контролю, релаксації та саморегуляції на базі зворотного зв'язку з Тілесним «Я». Програма «РІК» побудована на принципі поступового психічного поглиблення і розширення практики психічної інтеграції і передбачає послідовну реалізацію підготовчого, трьох основних (релаксація, обізнаність, імагінація) і завершального етапів. На основі узагальнення емпіричних даних показано, що, в результаті застосування оздоровчої психотехнології («РІК») виявлена позитивна динаміка суб'єктивної оцінки здоров'я і самопочуття, зниження інтенсивності соматичних скарг, гармонізація домінуючих психоемоційних станів, рівня вербалізації «тілесного Я» і емоційного прийняття свого тіла, що характеризує потенціал самооздоровлення і підтримання психосоматичного балансу особистості.

КЛЮЧОВІ СЛОВА: імагінативна психотерапія тіла, оздоровча психотехнология, тілесний локус контролю, релаксація, саморегуляція

\section{КОМПЛЕКС ПРИЕМОВ ИМАГИНАТИВНОЙ ПСИХОТЕРАПИИ ТЕЛА В ОЗДОРОВИТЕЛЬНОЙ ПСИХОТЕХНОЛОГИИ «РИК»: ЭФФЕКТИВНОСТЬ И ОСОБЕННОСТИ ПРИМЕНЕНИЯ}

Хомуленко Т.Б.

Доктор психологических наук, профессор, заведующий кафедрой практической психологии Харьковский начиональный педагогический университет имени Г. С. Сковороды

Крамченкова В.O.

Харьковский национальный педагогический университет имени Г. С. Сковороды

Фоменко К.И.

Харьковский национальный педагогический университет имени Г. С. Сковороды

Я.Л. Обухов-Козаровицкий

Снижение уровня здоровья рассматривается сегодня как социальная, общекультурная проблема. В современной Украине остро стоит проблема использования психологических технологий оздоровления, воспитания сознательного отношения к своему здоровью, что обусловлено противоречием между достаточно высокими объективными требованиями общества к здоровью, гармоничному развитию людей и достаточно низким уровнем бережного отношения к своему телу и оздоровительной культуры, а также общим ухудшением здоровья граждан. Статья посвящена разработке оздоровительной психотехнологии и оценке ее эффективности на основе исследования динамики вербализации телесного и субъективной оценки состояния здоровья в результате ее применения. Представлено обобщение результатов теоретического анализа проблемы здоровья, психологических механизмов его обеспечения. Обосновано применение интегративных психотехник в оздоровительных целях. Предложенная программа оздоровительной психотехнологии «Релаксация-имагинация-комфорт» («РИК») представляет собой одну из интегративных психотехнологий, базируется на синтезе приемов концентративного расслабления, имагнативной психотерапии тела и включает комплекс психотехник, направленных на обеспечение восстановления и сохранения полноценного функционирования организма, основанных на средствах интернализации телесного локуса контроля, релаксации и саморегуляции на базе обратной связи с Телесным «Я». Программа «РИК» построена на принципе постепенного психического углубления и расширения практики психической интеграции и предполагает последовательную реализацию подготовительного, трех основных (релаксация, осведомленность, имагинация) и завершающего этапов. На основе обобщения эмпирических данных показано, что, в результате применения оздоровительной психотехнологии («РИК») выявлена позитивная динамики субъективной оценки здоровья и самочувствия, снижение интенсивности соматических жалоб, гармонизация доминирующих психоэмоциональных состояний, уровня вербализации «телесного Я» и эмоционального принятия своего тела, что характеризует потенциал самооздоровления и поддержания психосоматического баланса личности.

КЛЮЧЕВЫЕ СЛОВА: имагинативная психотерапия тела, оздоровительная психотехнология, телесный локус контроля, релаксация, саморегуляция 